Preventive Veterinary Medicine Received on: $15 / 08 / 2018$ Accepted on: 10/08/2020

\title{
Prevalence and geographical distribution of bovine cysticercosis in the mesoregion of Northern Minas Gerais
}

Prevalência e distribuição geográfica de cisticercose bovina na mesorregião do Norte de Minas Gerais

OLIVEIRA, Laura Lúcia dos Santos ${ }^{1 *}$

https://orcid.org/0000-0002-0141-0242

SILVA, Fredson Vieira e $\mathrm{e}^{1}$

https://orcid.org/0000-0003-4341-0635

ALVES, Cleison Augusto ${ }^{1}$

https://orcid.org/0000-0002-8573-5190

BATISTA, Leandro Farias ${ }^{1}$

https://orcid.org/0000-0003-3979-6352
SOARES, Franklin Delano dos Santos ${ }^{1}$

https://orcid.org/0000-0001-7749-9338

ROCHA JÚNIOR, Vicente Ribeiro ${ }^{1}$

https://orcid.org/0000-0002-0721-1981

RUAS, José Reinaldo Mendes ${ }^{1}$

https://orcid.org/0000-0002-8824-2332

ALVES, Dorismar David ${ }^{1}$

https://orcid.org/0000-0003-4277-1498

${ }^{1}$ Departamento de Ciências Agrárias, Universidade Estadual de Montes Claros - Janaúba, MG, Brazil *

* Mailing address: laura.oliveira@unimontes.br

\section{ABSTRACT}

The knowledge of the prevalence of bovine cysticercosis is important for the implementation of control programs. The objective was to evaluate the prevalence and geographical distribution of bovine cysticercosis in Northern Minas Gerais. For that, 14,556 cattle were evaluated during the federal post-mortem inspection in 27 municipalities of five microregions: Janaúba, Montes Claros, Januária, Pirapora and Bocaiúva. The prevalence of Cysticercus bovis was $1.03 \%$ with distribution in all microregions evaluated of the northern Minas Gerais. All municipalities with a sampling number of cattle slaughtered above 543 showed positive animals for cysticercosis. The microregions of Bocaiúva, Montes Claros, Janaúba, Januária and Pirapora presented a prevalence of cysticercosis at $2.11 \%, 1.17 \%, 1.01 \%, 0.90 \%$ and $0.56 \%$, respectively. The microregions of Montes Claros and Januária presented a greater chance of finding positive cattle for cysticercosis. As there are positive cases of cysticercosis in all microregions evaluated, there is a risk to human health.

Keywords: Cysticercus bovis, public health, Taenia saginata, taeniasis

\section{RESUMO}


O conhecimento da prevalência da cisticercose bovina é importante para a implementação de programas de controle. Objetivou-se avaliar a prevalência e a distribuição geográfica de cisticercose bovina no Norte de Minas Gerais. Para isso, avaliou-se 14556 bovinos durante a inspeção federal post mortem provenientes de 27 municípios de cinco microrregiões: Janaúba, Montes Claros, Januária, Pirapora e Bocaiúva. A prevalência de Cysticercus bovis foi de $1,03 \%$ e está distribuída geograficamente em todas as microrregiões avaliadas do Norte de Minas Gerais avaliadas. Todos os municípios com número amostral de bovinos abatidos acima de 543 apresentaram animais positivos para cisticercose. As microrregiões de Bocaiúva, Montes Claros, Janaúba, Januária e Pirapora apresentaram prevalência de cisticercose de 2,11\%,1,17\%,1,01\%, 0,90\% e 0,56\%, respectivamente. As microrregiões de Montes Claros e Januária apresentaram maior chance de se encontrar bovinos positivos para cisticercose. Como há casos positivos de cisticercose em todas as microrregiões avaliadas, há risco a saúde dos seres humanos.

Palavras-chave: Cysticercus bovis, saúde pública, Taenia saginata, teníase

\section{INTRODUCTION}

The bovine taeniasis-cysticercosis complex can be defined as a set of pathological alterations caused by the adult and larval forms of Taenia saginata. This zoonosis can be expressed in two distinct forms, taeniasis, which affects human, or cysticercosis, caused by the presence of Cysticercus bovis in bovine tissues (Magalhães et al., 2017). Infection of humans with $T$. saginata is common in areas of the world where sanitation is inadequate (Usip et al., 2011; Acevedo Nieto et al., 2012). The parasite is commonly found in South America, North America and Africa (Usip et al., 2011), mainly in areas marginalized by public power.

The knowledge of the prevalence of bovine cysticercosis is important for the implementation of control programs (Acevedo Nieto et al., 2012). Anatomopathological diagnosis is the most important instrument in veterinary medicine, since the identification of cysticercosis at the time of animal slaughter is essential for the success of human taeniasis prevention programs (Côrtes, 2000).
Besides the damages imposed on human health, the economic aspect includes direct and indirect losses due to the disease in the animals. The carcasses or organs parasitized with cysticercus can have different destinations, depending on the degree of involvement, which causes economic losses to the beef supply chain (Laranjo-González et al., 2016) and, currently, synonymous with technical inadequacy in relation to the adoption of Good Production Practices (Rossi et al., 2014).

In view of the above, the goal was to evaluate the prevalence and geographical distribution of bovine cysticercosis in the northern region of the State of Minas Gerais.

\section{MATERIAL AND METHODS}

This cross-sectional study analyzed data from the slaughter of cattle from January to December 2010. Males and females aged between 20 and 60 months were slaughtered in a slaughterhouse with federal inspection, located in Janaúba, State of Minas Gerais, Brazil.

The State of Minas Gerais is divided into 12 mesoregions including the 
mesoregion of Northern Minas Gerais. In 2016, the cattle herd of the state was 23.8 million animals, and the North of Minas Gerais accounted for $10 \%$ total (IMA, 2017). The Northern region of Minas Gerais is divided into seven microregions, formed by 89 municipalities. All of the cattle avaluated were raised in some of the several farms of the Northern region. The prevalence of bovine cysticercosis was calculated from the diagnosis of confirmed cases of cysticercosis by visual inspection of the carcass performed by the federal inspection service (SIF). The animals from this data survey were raised on farms in 27 municipalities of five microregions, described in sequence. Microregion of Janaúba: Janaúba, Verdelândia, Pai Pedro, Jaíba, Matias Cardoso and Espinosa. Microregion of Montes Claros: Montes Claros, Capitão Enéas, Francisco Sá, Juramento, Mirabela, Claro dos Poções, São João da Lagoa, Coração de Jesus, Patis, Brasília de Minas, São João do Pacuí, São João da Ponte, Varzelândia and Ponto Chique. Microregion of Januária: Januária, Itacarambi, Manga, Pedras de Maria das Cruz and São Francisco. Microregion of Pirapora: Jequitaí. Microregion of Bocaiúva: Francisco Dumont.

The T-Test $(\mathrm{P}<0.05)$ was applied to check the prevalence of live or calcified cysts. The strength of association of prevalence and of microregions was calculated by Odds Ratio, where microregions with Odds Ratio $\geq 1$ and $\mathrm{P}<0.05$ were more likely to contain bovine cysticercosis. RStudio statistical program ("nlme" and "oddsratio" packages) was used.

\section{RESULTS}

The prevalence of Cysticercus bovis was $1.03 \%$ in 14,556 cattle evaluated. The number of live and calcified cysticerci was similar ( $53 \%$ vs. $47 \%$, respectively, $\mathrm{P}=0.3066)$.

Bovine cysticercosis is present in all microregions evaluated. The bovine cysticercosis was found in $19(70 \%)$ of the 27 municipalities evaluated as described in the sequence (Table 1 and Figure 1). The municipalities: Claro dos Poções, Patis, Varzelândia, Juramento, Mirabela, São João da Lagoa and Francisco Dumont had a higher apparent prevalence, all with values above $2 \%$. Considering the municipalities with the highest sample size ( $>543$ animals per municipality), the apparent prevalence of Cysticercus bovis ranged from 0.37 (Capitão Enéas) to $1.99 \%$ (São Francisco). 


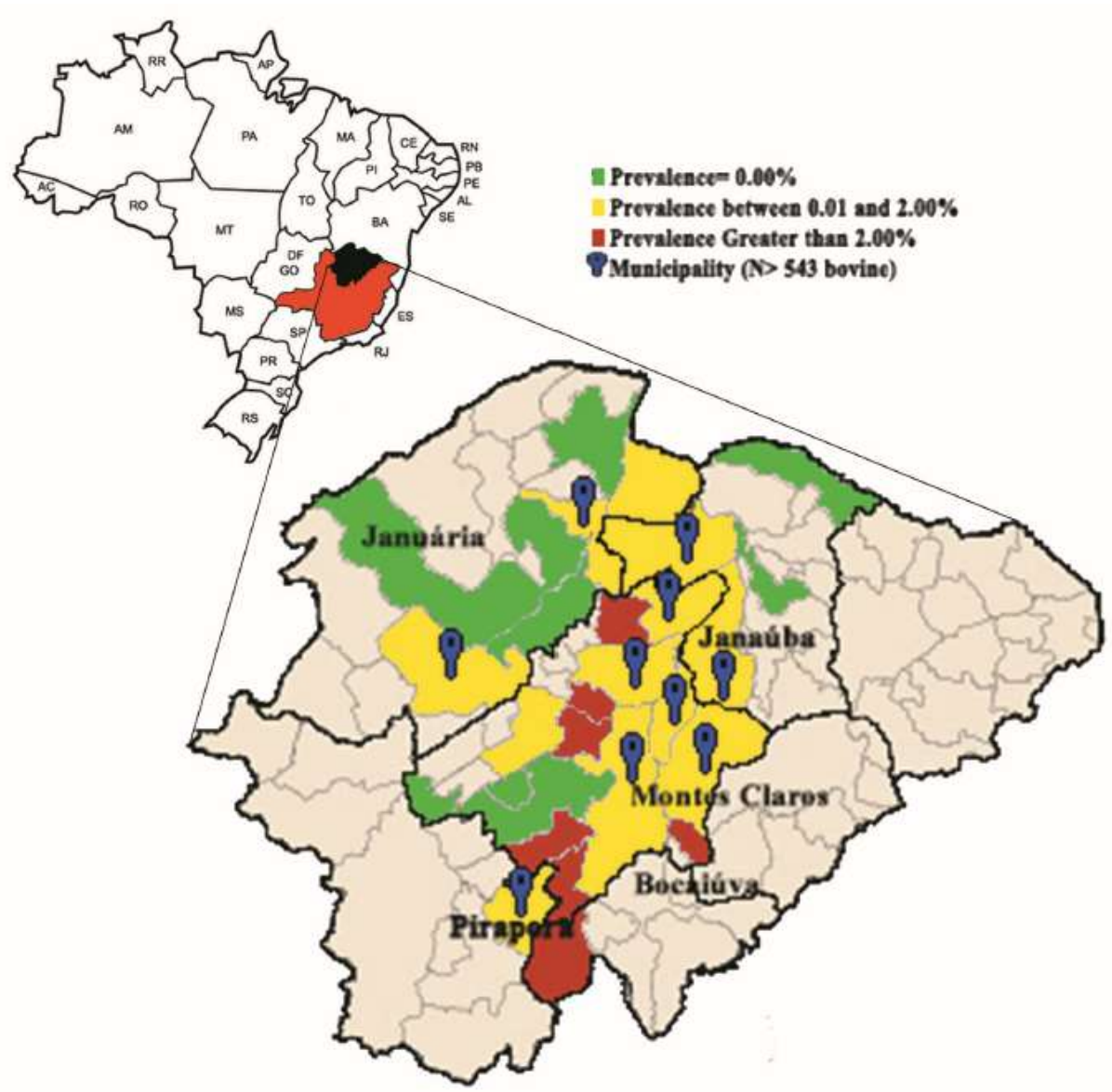

Figure 1. Geographical distribution of positive cases for bovine cysticercosis in the northern region of the State of Minas Gerais 
Table 1. Prevalence of the apparent bovine cysticercosis in 27 municipalities of the northern region of the State of Minas Gerais

\begin{tabular}{|c|c|c|}
\hline Municipality & Prevalence (\%) & Representativeness (\%) \\
\hline \multicolumn{3}{|l|}{ Microregion of Janaúba } \\
\hline Janaúba & 1.33 & 17.05 \\
\hline Matias Cardoso & 0.79 & 1.74 \\
\hline Verdelândia & 0.74 & 3.74 \\
\hline Jaíba & 0.71 & 10.66 \\
\hline Pai Pedro & 0.00 & 0.12 \\
\hline Espinosa & 0.00 & 0.55 \\
\hline \multicolumn{3}{|l|}{ Microregion of Montes } \\
\hline \multicolumn{3}{|l|}{ Claros } \\
\hline Claro dos Poções & 6.78 & 0.41 \\
\hline Patis & 4.25 & 1.46 \\
\hline Varzelândia & 3.33 & 0.21 \\
\hline Juramento & 2.86 & 0.24 \\
\hline Mirabela & 2.78 & 0.25 \\
\hline São João da Lagoa & 2.50 & 0.27 \\
\hline Montes Claros & 1.29 & 9.58 \\
\hline São João da Ponte & 1.28 & 8.59 \\
\hline Francisco Sá & 0.65 & 4.25 \\
\hline Brasília de Minas & 0.42 & 1.65 \\
\hline Capitão Enéas & 0.37 & 7.44 \\
\hline Coração de Jesus & 0.00 & 0.27 \\
\hline São João do Pacuí & 0.00 & 0.41 \\
\hline Ponto Chique & 0.00 & 0.14 \\
\hline \multicolumn{3}{|l|}{ Microregion of Januária } \\
\hline São Francisco & 1.99 & 3.79 \\
\hline Itacarambi & 0.72 & 18.95 \\
\hline Januária & 0.00 & 0.14 \\
\hline Manga & 0.00 & 0.47 \\
\hline Pedras de Maria da Cruz & 0.00 & 0.24 \\
\hline \multicolumn{3}{|l|}{ Microregion of Pirapora } \\
\hline Jequitaí & 0.56 & 6.08 \\
\hline \multicolumn{3}{|l|}{ Microregion of Bocaiúva } \\
\hline Francisco Dumont & 2.11 & 1.31 \\
\hline
\end{tabular}

When the apparent prevalence of Cysticercus bovis was evaluated according to the microregions of the northern region of Minas Gerais, the microregions of Bocaiúva and Montes Claros presented a higher prevalence of the disease (Table 2), followed by the microregions of Janaúba, Januária and Pirapora, in that order. The microregions of Montes Claros and Januária presented a greater chance of finding positive cattle for cysticercosis (Odds ratio $\geq 1$; $\mathrm{P}<0.05$ ). The microregion of Janaúba had a lower chance of finding positive 
cattle for the disease (Odds ratio $<1$; $\mathrm{P}$ $<0.05)$. For the microregions of Pirapora and Bocaiúva, there was no significant difference $(\mathrm{P}>0.05)$.

Table 2. Analysis of the association of microregions in the northern region of the State of Minas Gerais in relation to the prevalence of bovine cysticercosis

\begin{tabular}{|c|c|c|c|c|c|c|c|c|}
\hline \multirow{2}{*}{ Microregion } & \multirow{2}{*}{$\begin{array}{c}\text { Prevalence } \\
(\%)\end{array}$} & \multicolumn{2}{|c|}{ Percentile } & \multirow{2}{*}{$\underset{1}{\operatorname{Mun} .}$} & \multirow{2}{*}{$\begin{array}{c}\text { Rep. }^{2} \\
(\%)\end{array}$} & \multirow{2}{*}{$\begin{array}{l}\text { Odds } \\
\text { ratio }\end{array}$} & \multirow{2}{*}{$\begin{array}{c}\mathrm{Cl} \\
95 \%{ }^{3}\end{array}$} & \multirow{2}{*}{$\begin{array}{c}\text { P- } \\
\text { value }\end{array}$} \\
\hline & & Min & Max & & & & & \\
\hline Montes & 1.17 & 0.00 & 6.78 & 14 & 35.16 & 1.06 & $1.00-$ & 0.04 \\
\hline Claros & & & & & & & 1.12 & \\
\hline Janaúba & 1.01 & 0.00 & 1.33 & 6 & 33.86 & 0.81 & $\begin{array}{c}0.66- \\
0.99\end{array}$ & 0.03 \\
\hline Januária & 0.90 & 0.00 & 1.99 & 5 & 23.59 & 1.31 & $\begin{array}{c}1.09- \\
1.58\end{array}$ & 0.01 \\
\hline Pirapora & 0.56 & 0.56 & 0.56 & 1 & 6.08 & 0.00 & - & 0.64 \\
\hline Bocaiúva & 2.11 & 2.11 & 2.11 & 1 & 1.32 & 1.04 & - & 1.00 \\
\hline
\end{tabular}

${ }^{1}$ Number of municipalities, ${ }^{2}$ Representativeness, ${ }^{3}$ Confidence Interval.

\section{DISCUSSION}

As the majority of municipalities presented positive cases of cysticercosis, the sanitary conditions of cattle rearing properties should be improved, since they are related to the prevalence of the disease (Acevedo Nieto et al., 2012). As there have been cases of positive animals in all the municipalities of higher representativeness (> 543 animals per municipality), the problem is even more serious. São Francisco and Janaúba presented higher prevalence among the municipalities of higher representativeness.

The apparent prevalence recorded in this study, in general, is not considered endemic because, for the Pan American Health Organization, an endemic area has a prevalence above $5 \%$. Although the prevalence of cysticercosis in the municipality of Claro dos Poções is high, it cannot be considered endemic due to the small sample size. Magalhães et al. (2017), in the municipality of Salinas, State of Minas Gerais, reported a prevalence of $4.7 \%$ of bovine cysticercosis.

The prevalence of bovine cysticercosis is higher in regions where the population has low socioeconomic status (Queiroz et al., 2000). It is noted that, with the exception of Montes Claros, the municipalities evaluated in this study have an average HDI (Human Development Index), below the Brazilian average, and therefore, more serious health problems. Taking into account factors related to health and development, this mesoregion is also below the average of the State of Minas Gerais. For Pinto et al. (2019), the predominance of a low family income in the researched communities, accompanied by the respective implications of sanitary deficiency and low standard of knowledge, are indicative signs of the common occurrence of the disease.

The risk to humans in these microregions of Minas Gerais may be underestimated, as there are frequent cases of clandestine slaughter. Most of these municipalities do not have a slaughterhouse, which 
strengthens the previous assertion. Ferreira et al. (2014) reported that the lack of official inspection establishments may cause underreporting. In view of the above, municipalities that did not present positive cattle can be within this description, which suggests risk to humans.

Garro et al. (2015) reinforced the need to implement hygienic-sanitary and technological control in beef cattle production in São João Evangelista, State of Minas Gerais, since the consumption of raw uninspected meat was considered the main risk factor for the occurrence and maintenance of the bovine taeniasis-cysticercosis complex.

\section{CONCLUSION}

There are cases of bovine cysticercosis in the Northern region of the State of Minas Gerais, distributed in all microregions evaluated. For this reason, there is a risk to human health in this macroregion.

\section{ACKNOWLEDGEMENTS}

The authors thank Fundação de Amparo à Pesquisa de Minas Gerais- FAPEMIG, and the Conselho Nacional de Desenvolvimento Científico $e$ Tecnológico- $C N P q$.

This study was financed in part by the Coordenação de Aperfeiçoamento de Pessoal de Nivel Superior - Brasil (CAPES) - Finance Code 001.

\section{REFERENCES}

ACEVEDO-NIETO, E.C.; VIEIRA, F.C.; PINTO, P.S.A.; SILVA, L.F.; SANTOS, T.O.; PEIXOTO, R.P.M.G. Análise de fatores de risco para a infecção de cisticercose bovina: estudo de caso controle a partir de animais abatidos. Semina: Ciências Agrárias, v.33, n.6, p.2359-2366, 2012.

CÔRTES, J.A. Complexo teníase humana - Cisticercose bovina e suína II - Cisticercose bovina e suína. Revista de Educação Continuada em Medicina Veterinária e Zootecnia, v.3, n.2, p.61-71, 2000.

FERREIRA, M.M.; REVOREDO, T.B.; RAGAZZI, J.P.; SOARES, V.E.; FERRALDO, A.S.; MENDONÇA, R.P.; LOPES, W.D.Z. Prevalência, distribuição espacial e fatores de risco para cisticercose bovina no Estado de São Paulo. Pesquisa Veterinária Brasileira, v.34, n.12, p.1181-1185, 2014.

GARRO F.L.; SANTOS T.M.; ASSIS D.C.S.; HENEINE, L.G.D.;

ORNELLAS, C.B.D.; PINTO, P.S.A.; SANTOS, W.L.M. Diagnóstico do complexo teníase-cisticercose bovina em São João Evangelista, Minas Gerais, Brasil. Arquivos Brasileiro de Medicina Veterinária e Zootecnia, v.67, n.4, p.1063-1069, 2015.

LARANJO-GONZÁLEZ, M.;

DEVLEESSCHAUWER, B.; GABRIËL, S.; DORNY, P.; ALLEPUZ, A. Epidemiology, impact and control of bovine cysticercosis in Europe: a systematic review. Parasites \& Vectors, v.9, n.81, p.1-12, 2016.

MAGALHÃES, F.C.; SANTOS, T.M.; ASSIS, D.C.; ORNELLAS, C.D; PINTO, P.A.; SANTOS, W.M. Diagnóstico e fatores de risco do complexo teníase-cisticercose bovina no 
município de Salinas, Minas Gerais.

Pesquisa Veterinária Brasileira, v.37, n.3, p.205-209, 2017.

PINTO, P.S.A.; SANTOS, W.L.M.;

LAERTE, P.A.; ACEVETO-NIETO,

E.C.; SANTOS, T.O.; DUARTE,

C.T.D. Perfil epidemiológico da

cisticercose bovina e suína em três

regiões do estado de Minas Gerais,

Brasil. Arquivo Brasileiro de

Medicina Veterinária e Zootecnia, v.11, p.12-15, 2000.

QUEIROZ, R.P.V.; SANTOS, W.L.M.;

BARBOSA, H.V.; SOUZA, R.M.;

SANTOS FILHO, A.M.P. A

importância do diagnóstico da

cisticercose bovina. Revista Higiene

Alimentar, v.11, p.12-15, 2000.

ROSSI, G.A.M.; GRISÓLIO, A.P.R.;

PRATA, L.F.; BÜRGER, K.P.;

HOPPE, E.G.L. Situação da cisticercose bovina no Brasil. Semina: Ciências

Agrárias, v.35, n.2, p.927-938, 2014.

RSTUDIO TEAM. RStudio: Integrated

Development for R. RStudio, Inc.,

Boston, MA <http://www.rstudio.com/>.

2015.

USIP, L.P.E; ISAAC, L.; AMID, E.C. UTAH, E.C.; AKPAUDO, U. The occurrence of cysticercosis in cattle and taeniasis in man in Uyo, capital city of Akwa Ibom State, Nigeria. Journal of Food, Agriculture and Environment, v.7, n.2, p.47-51, 2011.

SEAPA. Secretaria de Estado de Agricultura, Pecuária e Abastecimento de Minas Gerais. Bovinocultura de leite e Corte. Acesso 10 de novembro de 2019. Disponível em:

$<$ http://www.agricultura.mg.gov.br/ima
ges/Arq_Relatorios/Pecuaria/2017/Mar/ bovinocultura_leite_corte_mar_2017.pd f>. 2017. 